\title{
Networking of Central European Artists' Associations via Exhibitions. The Slovenian Art Association, Czech Mánes and Polish Sztuka in Zagreb in the Early 20th Century
}

Kraševac, Irena; Šlosel, Petra

Source / Izvornik: Modern and Contemporary Artists' Networks. An Inquiry into Digital History of Art and Architecture, 2018, 16 - 36

Book chapter / Poglavlje u knjizi

Publication status / Verzija rada: Published version / Objavljena verzija rada (izdavačev PDF)

https://doi.org/10.31664/9789537875596.02

Permanent link / Trajna poveznica: https://urn.nsk.hr/urn:nbn:hr:254:222425

Rights / Prava: In copyright/Zaštićeno autorskim pravom.

Download date / Datum preuzimanja: 2023-04-26

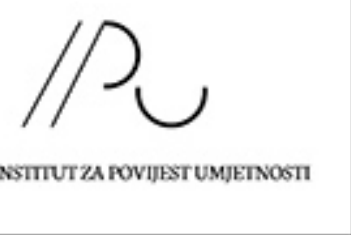

Repository / Repozitorij:

PODEST - Institute of Art History Repository

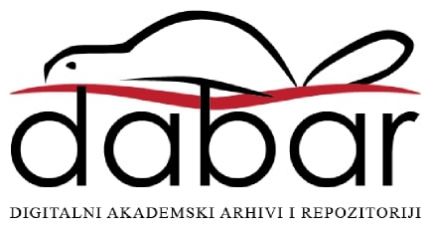


Networking of Central European Artists' Associations via Exhibitions. The Slovenian Art Association, Czech Mánes and Polish Sztuka in Zagreb in the Early 20th Century

DOI: https://doi.org/10.31664/9789537875596.02
The history of art exhibitions has become the subject of numerous scientific studies, particularly in the domain of the digital humanities, while exhibitions on exhibition are emerging as a distinct museologica variety, dealing with their reconstruction and the contextualization of art works in the time period of their conception. As a result of digitally processed data, exhibitions of art societies, as key points in the development of modern art, offer the possibility of a new way of viewing and interpreting the medium of the exhibition as such as well as the role and position of individual artists within a particular art association. ${ }^{23}$

The art scene developing in Central Europe, within the borders of the Austro-Hungarian Monarchy, at the turn of the 19th centu ry, which involved the artistic networking of groups and individuals through an exchange of exhibitions, guest exhibitions of art associations and the exhibitions of works by individual artists at various exhibitions and different Central European locations, showed exceptional dynamic activity and mobility. In this, the centra position was assumed by Vienna, a traditional hub of artistic life owing to the developed infrastructure based on its arts and crafts schools, Kunstgewerbeschule, and the Academy of Fine Arts, and the possibility of art exhibitions in the Künstlerhaus, the

23 A great example of this approach is the exhibition dedicated to the Vienna art association Hagenbund, organized by the Belvedere Gallery in 2014. See: Agnes Husslein-Arco, Matthias Boeckl, and Harald Krecji, eds., Hagenbund. Ein europäisches Netzwerk der Moderne 1900 bis 1938 exhibition catalogue (Vienna: Belvedere, 2014), and the digital and network display: Belvedere. "HAGENBUND. Ein europäisches Netzwerk der Moderne (1900 bis 1938)". Accessed January 5, 2019. http://tools.fas. at/hagenbund/exhibition.html.
Secession, Hagenbund and smaller private galleries. This potential was recognized by numerous artists from smaller and artistically less developed cities from othe parts of the Monarchy. Under the influence of Vienna's gravitational pull, within a very short time period comparable phenomena began developing in the wider region with local modernist artistic expression and their presentation via exhibitions growing stronger. The budding visual art scene would orient itself towards the leading artistic trends of the time, determined by the Secession and Hagenbund. Their impac was inevitable precisely due to the fact that a majority of artists from smaller art center of the Monarchy would come to Vienna for their education and would follow the development of the then modern art scene which attracted great attention, from both the artistic milieu and the wider audience. The artistic secessions that soon followed when groups of artists broke away from existing associations or established new ones stem from the 1897 to 1900 period. In this way, almost in succession, the following associations emerged: Associa tion of Austrian Visual Artists - Secession (Vereinigung bildender Künstler Österre ichs - Secession) and Hagenbund (Genossenschaft bildender Künstler - Hagen) in Vienna, the Association of Polish Artists "Art" (Towarzystwo Artystów Polskich "Sz tuka") in Krakow, the Association of Artists Mánes (Spolek výtvarných umělců "Mánes") in Prague, the Association of Croatian Artists (Društvo hrvatskih umjetnika) in Zagreb and the Slovenian Artistic Association (Slovensko umetniško društvo) in Ljubljana. The artistic interconnection and networking of individuals and groups was the centra subject of the interdisciplinary scientific project ARTNET-Modern and Contemporary Artists Practices of the 20th and 21st Centu$r y$, which explored the exhibitions of Croa- 
tian artists abroad, ${ }^{24}$ and the, until now less familiar, archival resources on exhibitions by foreign artists in Zagreb. ${ }^{25}$ In addition to exhibits of individual artists of various nationalities at annual and thematic group exhibitions of the Vienna Secession and Hagenbund associations, guest exhibitions of the then new artistic associations from Krakow and Prague were recorded in the exhibition spaces of these two associations, as well as their less known guest exhibitions in Zagreb at the very cusp of the 20th century. ${ }^{26}$ (Fig. 1)

24 Irena Kraševac, Željka Tonković, "Umjetničko umrežavanje putem izložaba u razdoblju rane moderne - sudjelovanje hrvatskih umjetnika na međunarodnim izložbama od 1891. do 1900. godine," Radovi Instituta za povijest umjetnosti, no. 40 (2016): 203-17. https://www.ipu.hr/content/radovi-ipu/ RIPU-40-2016 203-217 Krasevac Tonkovic.pdf

25 Irena Kraševac, ed., 150 godina Hrvatskog društva likovnih umjetnika. Umjetnost $i$ institucija (Zagreb: Croatian Association of Visual Artists, Institute of Art History, 2018); The work on the research project ARTNET - Modern and Contemporary Artists Practices of the 20th and 21st Century coincided with the marking of the 150th anniversary of the Croatian Association of Visual Artists (HDLU) (1868-2018). In parallel with the creation of the project CAN_IS database (Croatian Artists Network Information System), systematic work was carried out to catalogue the exhibitions that were held during the 150 years of HDLU's existence. From the very beginning, this task was assigned to Art Historian Petra šlosel, whose work was of key significance for the project from the outset because her dedication and experience contributed to the creation of the CAN IS database. Šlosel catalogued over 1.500 exhibitions organized by the then Art Society, today's Croatian Association of Visual Artists.
THE VIENNA SECESSION AND HAGENBUND - THE CREATION OF MODERN ART THROUGH AN EXCHANGE OF EXHIBITIONS

The example of the Sociéte des Artistes Indépendants, which revolted against the established exhibition politics of the traditional Société nationales des beaux-arts in Paris in 1884, and whose separation was termed "une sécession", inspired a series of similar secession art trends in the wide European cultural landscape. After a group of artists left the Munich Künstlergenossenschaft and established the Association of Visual Artists of Munich "Secession" (Verein Bildender Künstler Münchens "Secession") in 1892, a group of Viennese artists, led by Gustav Klimt, followed suit, resigning from the Künstlerhaus in 1897 and establishing the Association of Austrian Visual Artists-Secession (Verein bildender Kün stler Österreichs - Secession). The exhibition program carried out in the group' exhibition pavilion, constructed according to the conceptual idea of Klimt and the de-

and Piotr Mizia, "Sztuka-Wiener Secession Mánes. The central European Art Triangle," Artibus et Historiae, vol. 27, no. 53 (2006): 217-59.; Anna Brzyski, "Vienna Secession, Hagenbund, Szutka, and Mánes: competition and strategic collabora-

tion among central European art groups", Centropa, no. 11 (2011): 4-18. In very interesting articles discussing the interconnections of the exhibitions of the two renowned Viennese associations and the Polish and Czech associations, the guest exhibitions of the Sztuka and Mánes associations in Zagreb are not mentioned - something this article intends to make up for. This turns the "Central European artistic triangle" into a square, positioning Zagreb as a new (long neglected) artistic hub within the bounds of the Austro-Hungarian Monarchy. 
sign of architect J. M. Olbrich, best speaks to the group's openness to collaboration with contemporary artists throughout Europe. Thanks to numerous guest exhibitions, the Vienna art scene experienced a qualitative leap forward towards a modern artistic expression. ${ }^{27}$ Of Croatian artists, Ivan Meštrović was a regular member of the Vienna Secession, while other artists that participated in exhibitions as guests included Vlaho Bukovac, Antonija Krasnik and Tomislav Krizman

"Innovation through exchange" was the stance assumed by the second Viennese artistic association, Hagenbund, established in 1900, whose exhibition program would be shown in the converted premises of the former market building in the Zedlitzgasse (the so-called Zedlitzhhalle), according to the design of architect Josef Urban. Hagenbund would soon become the key platform of modern art in Central Europe, assuming a position between the avant-garde and the mainstream of the time, characterized by late impressionism and symbolism. Of Croatian artists, the association included Artur Oskar Alexander as a regular member, and hosted guest exhibitions by Tomislav Krizman, Ivan Meštrović, Emanuel Vidović and Lona von Zamboni. Owing to these two critical artistic associations, which were open to collaborating with younger and international artists, individual Croatian, Polish, Czech and Slovenian artists had the opportunity to exhibit their work in Vienna at the turn of the century. In their own countries, they would follow the example of the Viennese milieu and organize the artistic life of the then active younger generations, in opposition

27 Secession. Permanenz eine Idee, Wien, 1997; Marian Bisanz-Prakaken: Heiliger Frühling. Gustav Klimt und die Anfänge de Wiener Secession 1895-1905 (Wien-München: Christian Brandstätter Verlag, 1999) associations, attempting to obtain greater freedom of creation and exhibition. When shown at exhibitions organized by the Secession and Hagenbund, the works of Croatian artists were always exhibited individually, ${ }^{28}$ while the only collective guest exhibition to be organized by the Croatian Art Association in the Künstlerhaus in 1913 never came to fruition. ${ }^{29}$ On the other hand, Czech and Polish artists exhibited their work as part of both individual and collective guest exhibitions, which showed the recent works of the members of the associations Mánes and Sztuka. In the autumn of 1902, an exhibition of the Association Mánes in Hagenbund and the Association Sztuka in the Secession were organized simultaneously. ${ }^{30}$ The collabo-

28 For a detailed overview of the participation of Croatian artists at exhibitions in Vienna, see: Irena Kraševac, Petra Vugrinec, eds., Izazov moderne: Zagreb - Beč oko 1900, katalog izložbe (Zagreb: Galerija Klovićevi dvori, 2017), 289-291; Stella Rollig, Irena Kraševac, and Petra Vugrinec, The Challenge of Modernism: Vienna and Zagreb around 1900, exhibition catalogue (Vienna: Belvedere, 2017), 231; For Polish artists, see: Anna Brzyski-Long, "Unsere Polen...: Polish artist and the Vienna Secession 1897-1904", in: Art, culture and national identity in Fin-de-Siècle Europa, eds. Michelle Facos and Sharon L. Hirsch (Cambridge: 2003), 65-89.

29 HR-HDA-HDLU, 1979, 1.4.8.7., box 13. Izložba u Beču, 1912, letters regarding the organization of the exhibition of Croatian artists in the Künstlerhaus.

30 Agnes Husslein-Arco, et.a., Hagenbund, 124. The guest exhibition of the Czech Mánes was organized as part of the 4th Exhibition of the Association Hagenbund from 10th October to late November, while the Polish Association Sztuka participated in the 15th Exhibition of the Secession. ration of Mánes and the Hagenbund would continue with an exhibition of the Prague artists in Vienna in 1908, and reciprocal exhibitions by French artists in Prague in 1908 and 1909. The second guest exhibition of the Polish Sztuka Association in the Secession was organized in 1906, and an exhibition in the Hagenbund in the early spring of $1908 .^{31}$

\section{THE ASSOCIATION OF}

CROATIAN ARTISTS AND THE CROATIAN ART ASSOCIATION AS ORGANIZERS OF INTERNATIONAL EXHIBITIONS IN ZAGREB IN THE EARLY 2OTH CENTURY

Zagreb established itself as a Centra European center of art primarily due to the establishment of the Art Association in $1868 .{ }^{32}$ As opposed to the then cultural and artistic centres of Central Europe that Croatia was gravitating towards, Vienna and Munich, in which art associations were founded on a basis of an already well-established art scene and infrastructure, comprising a network of arts and craft schools, art academies and galleries, the specificity of the Zagreb scene was that the course of its development was the exact opposite - it was the establishment of the Art Association that would kick-start the foundation and creation of all those institutions that were fundamental for its activities and mission.

With the establishment and operation of

31 Agnes Husslein-Arco, et. al., Hagenbund, 141. Ausstellung der

Vereinigung polnischer Künstler "Sztuka", February - March 1908

32 0lga Maruševski: Društvo umjetnosti 1868.-1938.-1941. (Zagreb: The Croatian Society of Art Historians, 2004); Kraševac, 150 godina Hrvatskog društva the Art Association, focus was placed on artistic creation in a wider sense, fostering the appreciation of art works in the wide public and bolstering arts and crafts. It was only when the secession of a group of artists gathered around Vlaho Bukovac from the Art Association in 1897 that the paradigm would change. These artists advocated ar for its own sake, and emphasized the national character of the group, as expressed in the association's name Association of Croatian Artists. All of the group's artist had previous experience with the studios or exhibitions of the artistic milieus of Paris, Vienna and Munich, in which the secession associations caused media uproar and instigated a division of artists into "old" and "new". Based on Bukovac's efforts, the new internal rules of the Association were adopted, and Bukovac was appointed it President. Robert Frangeš was appointed Deputy President, and Rudolf Valdec Secretary of the Association. The Association's first members included Artur Oskar Alexander, Ivo Bauer, Menci Clement Crnčić, Bela Csikos Sesia, Oton Iveković and Ferdo Kovačević. These are the artists that launched Croatian modern art, declaring their intention to revive art through individual freedom, as demonstrated at the exhibition First Croatian Salon in the Ar Pavilion in 1898/1899. At the very turn of the century, in 1900/1991, the association held its Second Exhibition, hosting art works of the Slovenian Artistic Association from Ljubljana. As early as 1902, a joint exhibi tion of the Art Association and the Association of Croatian Artists was organized in the Art Pavilion, and the next exhibition held in 1903, demonstrated a fusion of both associations under the name Croatian Art Association. This shows that, in Croatian art history, rather than viewing the secession as a discontinuity within the Association, it should be understood as an indisputably sound and required interlude, after which 


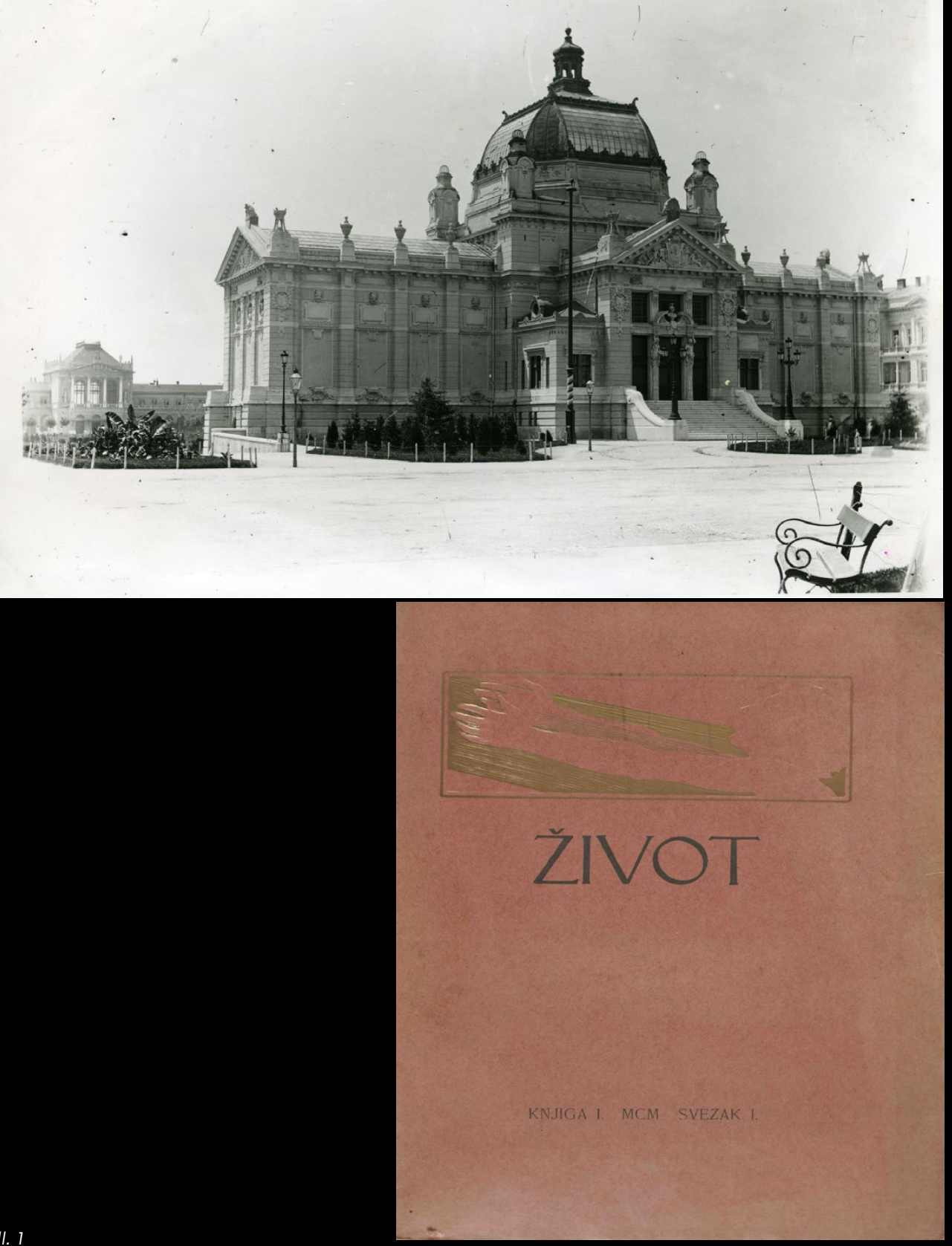

III. 1

The Art Pavilion in Zagreb around 1900, The Zagreb City Museum

III. 2 a more modern artistic expression and focus on artistic creation gained momen tum. Some of the important outcomes of the Croatian secession were certainly the opening of the Zagreb Art Pavilion as the first dedicated art exhibition space to be constructed in Zagreb (III. 1), the establishment of the Modern Gallery and the popularization of art in the public through exhibitions and the publication of the literature and art journal Život (Life) (III. 2)

Also, numerous guest exhibitions of art associations from Ljubljana, Prague and Krakow were organized during the first hal of the 20th century. The direct contacts made by Zagreb artists with artists from Prague and Krakow at exhibitions in $\mathrm{Vi}$ European associations, which simultaneously contributed to the internalization of minor artistic milieus, and triggered the national visibility of artists belonging to the Slavic parts of the multinational Monarchy. Their common endeavour was to propagate the value of modern art through a strategy involving exhibitions, art criticism, and the creation of a new form of artistic collaboration, which produced a new type of exhibition event - the guest exhibition.

SLOVENIAN ART ASSOCIATION (SLOVENSKO UMETNIŠKO DRUŠTVO) IN LJUBLJANA

The first signs of the organization of visua arts associations in Slovenia date back to 1898 and 1899, when the Slovenian Art Asso ciation was established in Ljubljana, which, in addition to painters, included sculptors graphic artists, literary and dramatic artists. Subsequently, this Association would separate into specialized artistic associations for the individual fields, among which the enna put Zagreb on the map of Centra

the Association of Slovenian Visual Artists (Društvo slovneskih upodabljajočih umetnikov) that exerted a strong influence on the entire Slovenian visual art of the 20th century. ${ }^{33}$ The Slovenian artists also took over the Munich and Vienna secessionism as their model of cultural politics. ${ }^{34}$

The first exhibition of the Slovenian Art Association was organized in 1900 in Ljubljana, gathering 31 Slovenian artists, most of which lived in Ljubljana and Slovenia at th time, and a few notable artists with career abroad or who were outside the country, in Munich or Vienna, at the time when the exhibition was held. With 186 paintings and sculptures exhibited, this was the larges exhibition held in Ljubljana at the time. ${ }^{35}$ Thanks to the contacts between Slovenian and Croatian artists, members of the Slovenian Art Association participated in the Second Exhibition of the Association of Croatian Artists in Zagreb, held in the Art Pavilion in 1900/1901 ${ }^{36}$ (III. 3). After the great

33 Ida Tomše, "Institucionalizacija slovenske likovne umetnosti od 1900 do 1941," Peristil, no. 31 (1988): 181-84.

34 Beti Žerovc: Slovenski impresionisti (Ljubljana: Mladinska knjiga, 2013), 19

35 Fran Goveker, ed, Seznam in imenik I. slovenske umetniške razstave (Ljubljana:

Slovensko umetniško drušvo, 1900). The exhibition was held from 15 September to 15 0ctober 1900. The Commission for the selection of exhibits included Ivan Franke, Imperial advisor and professor, painter, Ivan Duffé, city advisor, Celestin Mess, professor and sculptor, and the painters Ferdinand Vesel and Matej Sternen, while the organization of the exhibition was entrusted to the painters Ivan Grohar and Rikard Jakopič

36 The exhibition was held from 22 December 1900 to 25 January 1901, according to the selection of the same commission, see note 13. http://dizbi.hazu. most prominent position was assumed by $\mathrm{hr} /$ ?object=list\&find=druga+iz10\%C5\%BE- 
DRUŠTVA HRVATSKIH UMJETNIKA

U UMJETNIČKOM

PAVILJONU U ZAGREBU

OTVORENA OD 22

PROSINCA 1900 DO

25. SIEČNJA 1901
Fig. 2 success of the Croatian Salon in 1898/1899, this was the first subsequent and last exhibition to be organized by this Association. Internal disputes that began to plague the Association of Croatian Artists resulted in the departure of the association's most agile artists - after the departure of it President Vlaho Bukovac for Cavtat, and then to Vienna and Prague, the Association lost its young promising artists Rober Auer i Bela Csikos Sesia, who left for New York. At the same time, the Association of Croatian Literary Artists was faced with difficulties regarding the publication of it journal Život, and was embroiled in a laten dispute with the Art Association, dominated by Iso Kršnjavi, resulting in the closing of the association. After Bukovac, Menci Clement Crnčić took over as President of the Association of Croatian Artists, thanks to whose efforts a new exhibition was organized from 22 December 1900 to 25 January 1901. The exhibition comprised three rather disparate parts: I. Exhibition of the Slovenian Art Association in Ljubljana, II. Collective Exhibition of M. Cl. Crnčić, and III. Alphon Mucha Exhibition. The part of the exhibi tion devoted to the first collective gues exhibition of Slovenian artists in Zagreb involved 15 male and three female artists: the painters Antun Ažbe, France Berneker, Ivan Franke, Ivan Grohar, Anton Gvajc, Rikard Jakopič, Marija Jama, Antun Koželj, Matej Šernern, Ferdo Vesel i P. Žmitek, sculptor B. Pogačnik, Alojzij Repič, Ivan Zajc i Jakob Žnider, and the female painters Ivana Kobilca, Henrika Šantel and Jessie Vesel. The exhibition comprised 127 works that had just before been shown at an exhibition in Ljubljana, ${ }^{37}$ arousing great interest of the

37 Cf. the network display of the First exhibition of the Slovenian Art Association in Ljubljana in 1900 and the exhibition of the Slovenian Art
Zagreb public and critics. Vladimir Lunaček pointed out the works by Rikard Jakopič and Matija Jama as the "most modern and fresh paintings", also commending the exhibits of the three female artists. ${ }^{38}$ The critique of Iso Kršnjavi included an interesting comment that could equally apply to numerous other exhibitions of the time, which often merely threw art works together uncritically: "On cannot really judge Slovenian artists based on this exhibition: had they exhibited les works, it would have been better. Had they shown us the best works of their best artists, the entire exhibition would have been a success, but this slew of failed paintings by bad and good artists blights the overall succes of Slovenian painters." ${ }^{39}$ In any case, this exhibition prompted guest exhibitions of foreign art associations in the Art Pavilion in Zagreb, followed by guest exhibitions of the Czech Association Mánes and the Polish Association Sztuka.

Among the guest exhibitions processed, for the purposes of this article, using digita network visualization tools developed as part of the ARTNET scientific projects, the exhibition of the Slovenian Art Association in the Zagreb Art Pavilion was specific in the sense that the guest exhibition of the Slovenian artists was held in Zagreb a the end of the same year in which the first exhibition of this Association had already

Exhibition of the Association of Croatian Artists in Zagreb in 1900/01.

38 Vladimir Lunaček, "Slovenski umjetnici," Život, no. 1 (1901): 6-13.

39 Izidor Kršnjavi, "Druga izložba Društva hrvatskih umjetnika, I. Slovenski slikari," Narodne novine (31 December 1900); reprint: Isidor Kršnjavi, Listovi iz Slavonije - Članci, ed. Katica Čorkalo (Vinkovci: Vinkovci Branch of the Matrix Croatia, Croatian Academy of Sciences and Arts. Vinkovci Center for Scientific Research, 1995), 313-319. 
been held in Ljubljana. Taking into account the relatively short period between the two exhibitions of the newly established Association, it should come as no surprise that the Zagreb exhibition involved exclusively artists that had already exhibited thei works in Ljubljana, whereby the number of artists in Zagreb was considerably smaller. The network display of these two exhibitions held in 1900, first in Ljubljana and then in Zagreb (Fig. 2), shows that the red nodes representing the artists who participated in both exhibitions are located between the blue nodes, which represent the exhibitions, whereas the red nodes representing the artists who only participated in the Ljubljana exhibition remain on the periphery of the display, outside of the in tersection area. This clearly demonstrate that all artists whose works were shown in Zagreb had previously participated in the first exhibition of their association in Ljubljana.

The network display of all guest exhibitions covered by this analysis (Figl. 3) also indicates the isolated position of the 1900 exhibitions held in Ljubljana and Zagreb in relation to other exhibitions taking into consideration that the collective guest exhibition of the Slovenian Art Association in Zagreb was also the only guest exhibition of works by Slovenian artists organised abroad. They are linked to the rest of the network via the guest exhibition organized by Association of Croatian Artists (represented with an orange node) and the exhibition space of the Art Pavilion (represented with a green node) as the venue of the guest exhibition of the Czech Art Association Mánes organised in 1904 and of the Polish Art Association Sztuka organised in 1911.
THE MÁNES ASSOCIATION OF FINE ARTISTS (SPOLEK VÝTVARNÝCH UMĚLCŮ „MÁNES“) IN PRAGUE

The Czech art association emerged from a group of Czech students in Munich that took its name in 1890 after the renowned romanticist painter Josef Mánes. Mikoláš Aleš was the first president of the association. The association gathered painters sculptors, architects, writers and art critics like Otto Gutfreund, Karel Hlavaček, Vratislav Hofman, Bohumil Kavka, Jan Kotěra, Josef Mařatka, Vladimir Županský, Antonin Hudeček, Jindřich Průcha, Antonin Slaviček, Joža Úprka, Max Švabinský, Jan Preisler and many others. They organised their first exhibition in 1898 together with a journal named Volné Smerry in which they published their aims and objectives and emphasised the importance of organising exhibitions of works by Czech and other European artists as well as fostering of artistic individuality. ${ }^{40}$ The exhibitions of works by foreign artists organised in Prague by The Mánes Association of Fine Artists left an important mark in the history of Czech art exhibitions, starting from 1902 and the exhibition of works by August Rodin to the exhibition of French avant-garde artist organised in 1914, which had a significant impact on Czech artists resulting in their inclination toward cubism.

The Mánes Association of Fine Artists from Prague presented the works of its members in Vienna at the 4th Hagenbund exhibition held in 1902. The exhibition was held in parallel with the exhibition of the Polish Sztuka Association, which had a guest exhibition at the Secession, thus demonstrating the openness of Vienna to art phenomena in other (national) centres of the Monarchy.

40 Krzysztofowicz-Kozakowska and Mizia "Sztuka-Wiener Secession-Mánes. The central European Art Triangle," 225.
Exhibitions of Central European artists' associations in the period from 1900 to 1911 (artists' associations, exhibitions and participants) 
Viennese critics, primarily Ludwig Hevesi and Berta Zuckerkandl, pointed out the importance of Švabinski, Uprka, Slaviček, Hudeček and Preisler together with Kupka and Šimon, as young raising stars. 41 Hagenbund achieved a very good collaboration with the Mánes in Prague, which evolved in one of the most fruitful international art networks. ${ }^{42}$

The connection between Prague and Zagreb resulted in guest exhibitions presenting works by Croatian artists at the Mánes Pavilion in 1903 and a reciprocal exhibition of the Mánes Association the Art Pavilion organised in May 1904. Documentation about those exhibitions has been preserved thanks to catalogues supported by the historical archives ${ }^{43}$ (III. 4) The works by the following Croatian artists were presented in Prague at the 10th exhibition organised by the Mánes Association: Josip Bauer, Vlaho Bukovac, Joso Bužan, Menci Clement Crnčić, Bela Csikos Sesia, Tomislav Krizman, Ferdo Kovačević, sculptors Robert Frangeš, Ivan Meštrović and Rudolf Valdec together with Slava Raškaj as the only female artist. As many as 192 works by Czech artists were transported for the exhibition held in Zagreb including works by Rudolf

41 Agnes Husslein-Arco, et. al. Hagenbund, p. 124.; http://digi-

tale-bibliothek.belvedere.at/viewer/ image/1411477732019/1/LOG_0000/

42 Agnes Husslein-Arco, et. al., Hagenbundi digital http://http://tools fas.at/hagenbund/exhibition.html; http:// digitale-bibliothek.belvedere.at/viewer/ image/1412675348091/1/

43 The Croatian Academy of Sciences and Art, Fine Arts Archives, Documentation on the exhibitions held in Zagreb, Envelope F 594, the exhibition of the Manes Association. http://dizbi.hazu. hr/object/1660; http://dizbi.hazu.hr/?object $=1$ ist\&find $=k$ atalog $+i z 10 \% \mathrm{C} 5 \% \mathrm{BE}-$ be+manes+zagreb insa, Antonin Hudeček, Josef Jelínek, Miloš Jiránek, Dušan Jurković, Franta Kavan, Ladislav Kofránek, František Kupka, Richard Lauda, Stanislav Lolek, Josef Loukota, Josef Mařatka, František Pečínka, Antoniín Slavíček, Viktor Stretti, František Šimon, Max Švabinský, J. Tomec, Jóža Uprka, František Voves, sculptors František Bílek, Buhumil Kafka, Josef Kratina, Stanislav Sucharda, Ladislav Šaloun, O. Španiel, Jan Štursa, architects Jan Kotěra and J. Letzel, and a single female artist, Anna Boudová.

Iso Kršnjavi commented the collaboration by saying the following:

Exhibitions like this one have to be observed from a practical point of view. No matter how his profession might be noble and beautiful, an artist has to live of his work and he needs to, as any other worker, look for a compensation, wherever he might find one. ${ }^{44}$

Apart from the review of art critique re-affirming art creation in particular countries, one of the results of the exhibition was selling of artworks by Croatian artists in Prague as well as selling of artworks by Czech artists in Zagreb, out of which the wooden relief showing Jesus and Magdalena by František Bílek became one of the first acquisitions of the collection of the Modern Gallery in Zagreb, founded in 1905. ${ }^{45}$

44 Izidor Kršnjavi, "Naša umjetnost", Narodne novine, no. 261 (14 November 1903): 245 45 The Croatian Academy of Sciences and Art, Fine Arts Archives, Documentation on the exhibitions held in Zagreb, Envelope F 594, The exhibition of the Manes Association of Fine Artists. The records indicate that works by Bela Csikos Sesia, Menci Klement Crnčić, and Josip Bauer were sold in Prague, while works by the Czech artists Josef Kratina, Stanislav Lolek, Antonin Slaviček, Viktor Stretti, Stanislav 
The network display of all guest exhibitions covered here (Fig. 3) indicates the four exhibitions associated with the The Mánes Association of Fine Artists located next to the left margin of the network. Having in mind that they do not have any participants in common, the guest exhibition of Croatian artists organised by the Mánes in Prague in 1903 is located more marginally in relation to the three exhibitions of works by Czech artist organised in Vienna in 1902 and 1908 and in Zagreb in 1904. In the part of the network display linked to the three guest exhibitions of Czech artists organised abroad, six groups of red nodes indicate the Czech artists. Three groups of nodes located marginally next to blue nodes, which indicate the exhibitions, present those artists who exhibited their works in the framework of a single and corresponding exhibition while three groups of red nodes located inside of the field bounded by blue nodes for the three exhibitions indicate the artists who participated in several exhibitions. At the same time, the central position is taken by the group of seven artists whose works were showcased on all the three exhibitions. Visualisation of the network clearly suggests that the exhibitions held in a short period of time, i.e. in Vienna in 1902 and in Zagreb in 1904, comprised a significantly higher number of common participants (19) in comparison to the parallel display of the two exhibitions in Vienna (7) or the exhibition held in Zagreb and subsequently the one held in Vienna (10).

THE ASSOCIATION OF POLISH ARTISTS "ART" (TOWARZYSTWO ARTYSTÓW POLSKIH

"SZTUKA") IN KRAKOW

The Association of Polish Artists Sztuka was established in opposition to then official The Association of Friends of Fine Arts in Krakow and Lvov. Józef Chetmoński and in Paris. A Separate Exhibition of Painting and Sculpture was organised in 1897 in Krakow and in November a new association was founded with the aim "to improve artistic life in the homeland and organise exhibitions both at home and abroad." 46 This international cooperation comprised a number of exhibitions during the period 1897-1914 in the following cities: Vienna, St. Louis, Munich, Düsseldorf, Antwerp, Leipzig, Dresden, Rome, Venice, Prague, Budapest and Berlin. ${ }^{47}$ Having in mind that the Association of Polish Artists Sztuka appeared in public relatively frequently and that Polish artist had an open access to the European art market, the Association was not very active in organising reciprocal exhibitions of other art associations in Krakow. ${ }^{48}$

Polish artists had individual exhibitions organised in the Secession in Vienna, ${ }^{49}$ and the first group exhibition of works by the members of the Sztuka Association was organised in the autumn of 1902 at the Secession Pavilion in the framework of their $15^{\text {th }}$ exhibition50. The critics praised it - Ludwig Hevesi in particular who wrote about the national character of the Polish exhibition, describing it as a "grand pussée

46 Krzysztofowicz-Kozakowska and Mizia, Sztuka-Wiener Secession-Mánes. The central European Art Triangle," 219-20.

47 Ibid, 219; Brzyski, "Vienna Secession, Hagenbund, Sztuka and Mánes: competition and strategic collaboration among central Europen art grups," 4-18.

48 Krzysztofowicz-Kozakowska and Mizia, "Sztuka-Wiener Secession-Mánes. The central European Art Triangle," 219. There was only one guest exhibition recorded, that of the Mánes Association in Krakow.

49 Ibid, 221, note 25

50 Ibid, http://digitale-bibliothek.belvedere.at/viewer/image/1413884320733/1/

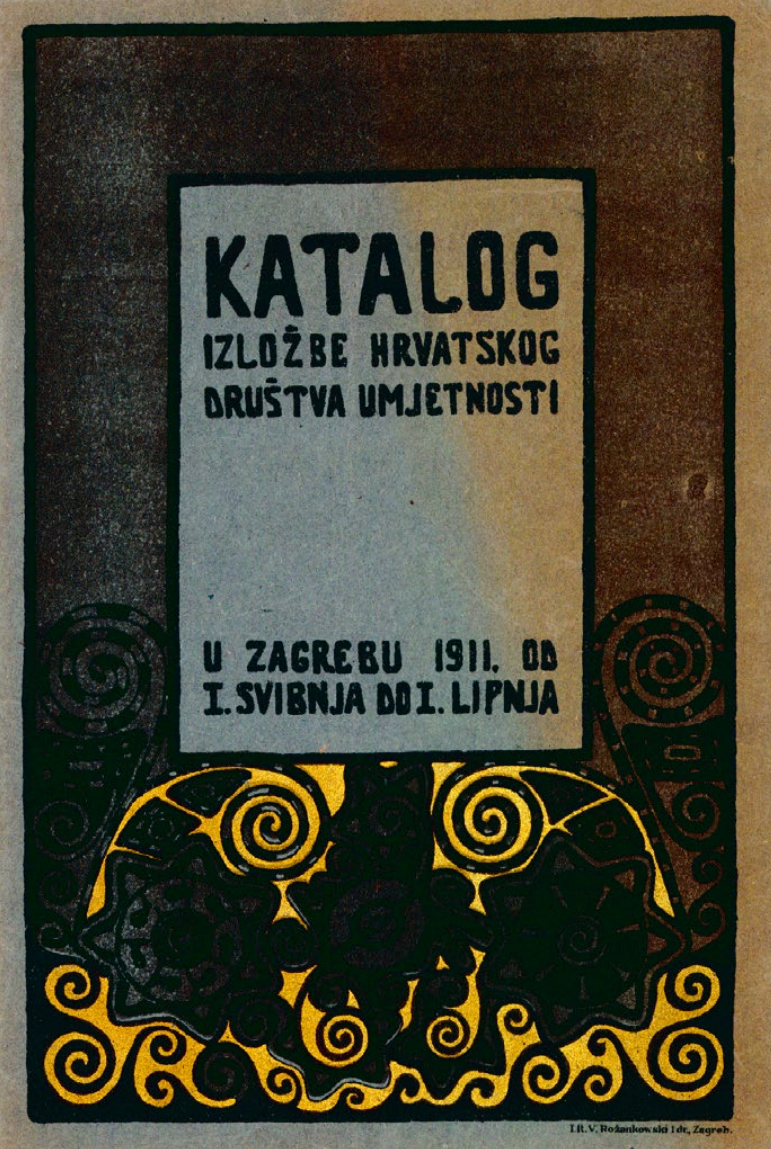

III. 5

The catalogue of the exhibition of the Croatian Art Association, The Art Pavilion in Zagreb, 1911. The Croatian Academy of Sciences and Art - Fine Arts Archives, Zagreb 
de tristesse", and emphasising the quality of the painters such as Józef Mehoffer, Stanislav Wyspiański, Ruszczyc, Leo WyCzólkowski and Kontanty Laszceska. ${ }^{51}$ The next exhibition of the Sztuka Association at the Secession in Vienna followed in 1906, with a prominent appearance of works by Jan Stanislavski, Ferdynand Ruzczyc and Karol Frycz. ${ }^{52}$

Polish researchers were unable to establish if the Association of Polish Artists Sztuka had a guest exhibition organised in Zagreb in $1911^{53}$ (III. 5). The Art Pavilion organised the exhibitions of works by Polish artists, members of the Sztuka Association and members of the Croatian Art Association in parallel, which provided a possibility to compare and critically appraise the two national segments of art production. Polish artists were present with 82 artworks as follows: 17 painters: Teodor Axentowicz, Stanislav Czajkowski, Stefan Filipkiewicz, Gustaw Gwozdecki, Vlastimil Hoffmann, François Jabtczynski, Wladislav Jarocki, Alfons Karpinski, Josef Krasnowolski, Jozef Mehoffer, Tymon Niesiolowski, , Stanislav Podgorski, Ignacy Pienkowski, Jan Rubczak, Ferdinand Ruszczyc, Jan Stanislawski and Wojciech Weiss, 2 sculptors: Henrik Glicenstein, Bronislav Pelczarski, and one female painter, Olga Boznańska. Croatian artists were presented by the works by Robert Auer, Leopoldina Auer-Schimdt, Ivan Benković, Anka Bestall, Joso Bužan, Menci Klement Crnčić, Bela Csikos Sesia,

51 Ibid.

52 Krzysztofowicz-Kozakowska and Mizia, "Sztuka-Wiener Secession-Mánes. The central European Art Triangle," 224; http:// digitale-bibliothek.belvedere.at/viewer/ image/1414425130841/1/L0G_0000/

53 Katalog izložbe Hrvatskog društva umjetnosti : u Zagrebu 1911. od 1. svibnja do 1. lipnja (Zagreb: Dionička tiskara u Zagrebu, 1911)
Robert Frangeš Mihanović, Oton Iveković, Jenčik, Ferdo Kovačević, Miroslav Kraljević, Anka Löwenthal Maroičić, Celestin Medović, Franjo Pavačić, Zdenka Pexidr-Srića, Zora Preradović, Elsa Rechnitz, Iva Simonović, Jelka Stuppi, Branko Šenoa, Nasta Šenoa-Rojc, Rudolf Spiegler, Antun Štefic and Rudolf M. Valić. Andrija Milčinović described the unconventional artistic vibrancy of the two art associations and nations, very much visible at this exhibition, by saying:

This wall around us does not allow us to breathe or to live. Our artists invited the Association of Polish Artists Sztuka in this politically charged atmosphere. One may support any kind of artistic perspective, one may foster artistic values in everything produced over the past few decades or one may neglect everything that piled up in old galleries; one may also be a vigorous opponent of this or that group, however, one must admit that inviting the members of the Sztuka to Zagreb is a great merit of the Art Association. The Art Association had invited the Czech artists from the Mánes at the time, it invited Vereščagin, Slovenian artists, Serbs and Bulgarians but never had they made such a distinct choice like in the case of the Sztuka. That act stands as a proof of self-awareness, enthusiasm, and patriotism to such an extent that one remains taken aback wondering: is this possible? Is it possible to inspire so much life, so much diversity and young aspiration and intention by way of presenting so many already established artistic directions and significant artworks having recently emerged from those artistic directions. One cannot do anything but ask how is it that those paintings do not fall off the walls and those sculptures off their pedestals out of fear from that vehement antipathy, that disapproval and resistance so characteristic for such a heavy and suffocating atmosphere?... Upon inspecting all works by the Polish artists, one simply has to make the conclusion: The Poles do not know us, that is rathe obvious, otherwise they would have not sent the works of art that so ruthlessly disturb our peace and 'calm' behind which we are hiding. (..) Nowadays, the Poles are most certainly the first among the Slaves in doing so because they were successful in preserving their authenticity while marching next to the French and the others who had opened the new horizons in art. And although they live in different cities and different parts of the country, in many ways they stand as one. A few more exhibitions like this and maybe the artistic life in Zagreb will breathe the life it was breathing ten or fifteen years ago. It is better to remain unpopular, criticised and even persecuted than adored and close to the audience that still has not developed a real interest in art. ${ }^{54}$

The critic evokes the inspiring and competitive early modern period before the First Croatian Salon and "the suffocating atmosphere" of the artistic life in Zagreb was a reflection of turbulent events taking place after the separation of a group of young Croatian artists that participated at the International Exhibition in Rome in parallel with this exhibition and thus showed

Andrija Milčinović, "Umjetnička izložba," Savremenik, no. 8 (1911), 526-529. in the framework of the network display of all of all guest exhibitions covered here (Fig 3), the position of The Association of Polis Artists Sztuka is closest to the centre owing to the highest number of group exhibitions held according to the parameters attributed to the guest exhibitions organised by other central European art association (five exhibitions in total), but also owing to the highest number of collaboration with other associations by way of cultural exchange in the form of exhibitions. As opposed to the Mánes Association, whose appearances in Vienna were organised exclusively by Hagenbund, the network display clearly indicates that the Association of Polish Artists Sztuka had two exhibitions organised at the Secession (one in 1902 and one in 1906) together with the exhibitions organised at the Hagenbund in Vienna (two exhibitions in 1908).

The position of red nodes representing Polish artists in relation to blue nodes in dicating the exhibitions to which they are linked depending on their participation in this case reveals that those artists whose works were presented at one exhibition hold marginal positions on the network display on the one hand, and a more central position in the network of interconnections between the artists who took part in more than one exhibition on the other. Five artist who took part in all five group exhibitions of the works by the members of the Sztuk are located at the centre i.e. Teodor Axentowicz, Józef Mehoffer, Jan Stanisławski, Wojciech Weiss and Olga Boznańska as the only female artists.

55 Sandi Bulimbašić: Društvo hrvatskih umjetnika "Medulić " (1908-1919) umjetnost i politika (Zagreb: The Croatian Society of Art Historians, 2016), 227-259. 
In addition to individual appearances on the exhibitions at the Secession and the Hagenbund in Vienna, both of which served as platforms for organising exhibitions to present modern art from Central Europe and meeting points and places to learns about artists from other parts of the Monarchy, a special attention was given to guest exhibitions presenting the work of art associations organised between Vienna, Krakow, Prague and Zagreb. In Vienna, The Association of Polish Artists Sztuka had two guest exhibitions organised at the Secession in 1902 and 1906 and one exhibition at the Hagenbund in 1908 followed by one exhibition organised in Zagreb in 1911. The Mánes Association of Fine Artists had two exhibitions organised at the Hagenbund in 1902 and 1908, respectively and in 1904 they exhibited their works in Zagreb as a reciprocal visit following the guest exhibition of the Croatian Art Association in Prague in 1903. Taking into account that the guest exhibitions of the Mánes and the Sztuka art associations that took place in Zagreb have not been in the focus of any research done by Czech or Polish art historians so far, by extending the network of exhibitions to cover Zagreb we are contributing to the network of modern art in Central Europe during the first decade of the $20^{\text {th }}$ century by adding another overlooked art centre. Visualisation of digital data by way of different networks indicating artistic collaboration between art associations and artists demonstrates a rather high number of artists coming from the Slavic regions of the Monarchy whose works were exhibited thanks to organised guest exhibitions. All these art associations also included works by female artists although their number was limited i.e. only seven female painters in total exhibited their works. Ivana Kobilca, as a member of the Slovenian Art Association,

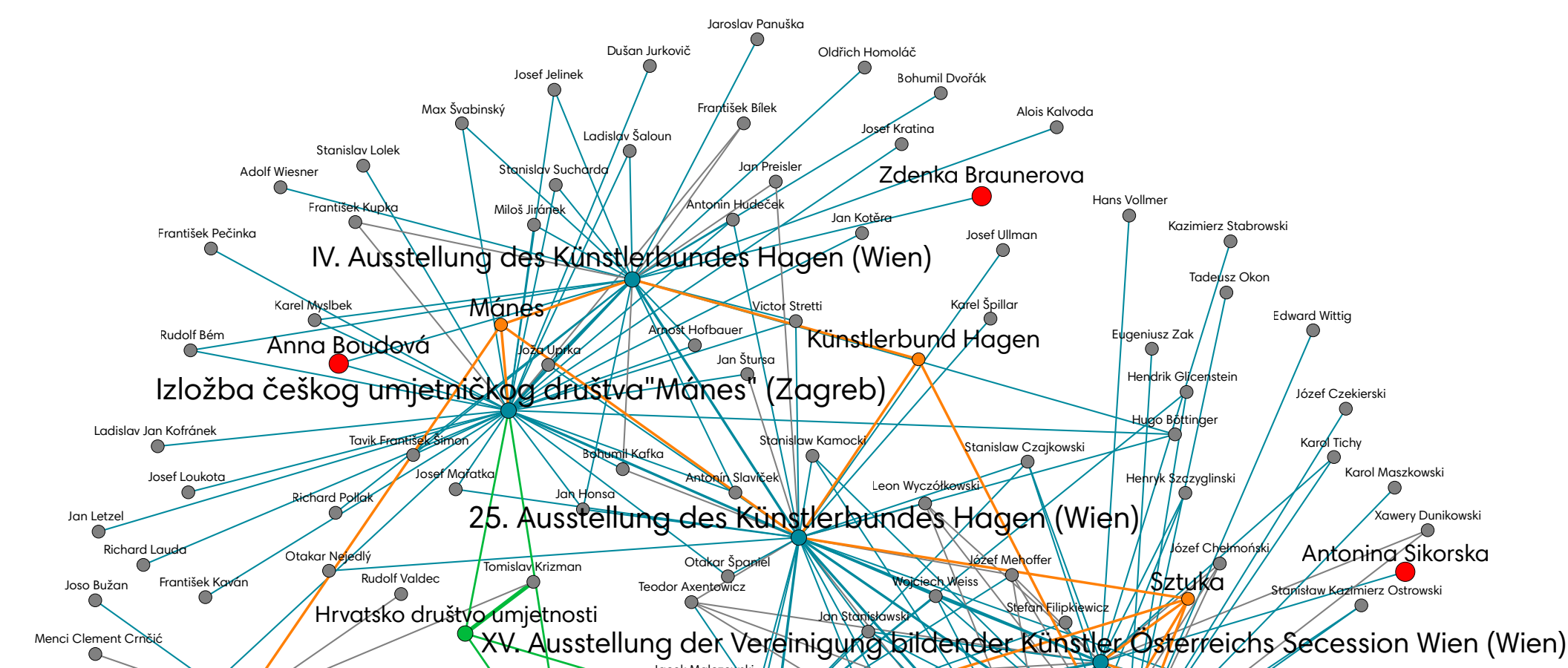

X. výstava sporlkư Mánes" (Prag)
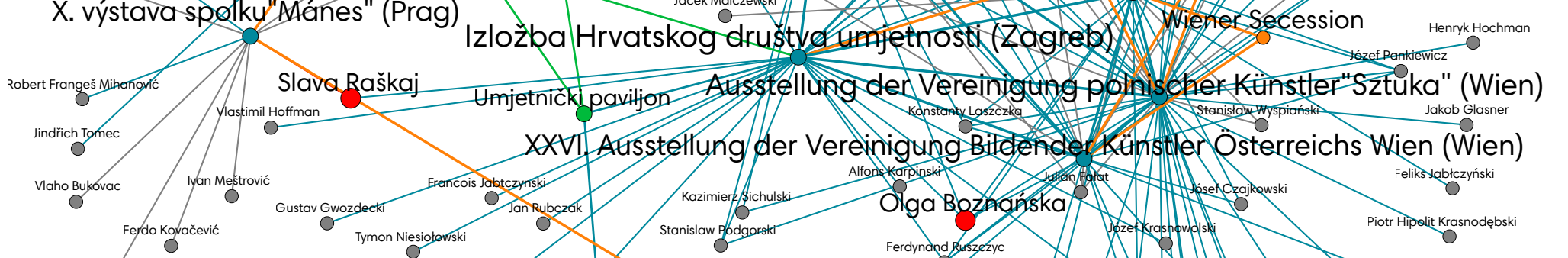

Fig. 4

Exhibitions of Central European artists' association in the period from 1900 to 1911 (red nodes present women artist participating in the exhibitions) 
map2_1962-1963.pdf stands out with the quality of her paintings and the number of exhibitions in which she participated, the Association of Polish Artists Sztuka regularly included painter Olga Boznańska, while Anna Boudová exhibited her works together with other members of the Czech Mánes..$^{56}$ The network display comprises 147 artists in total: 89 painters, 26 sculptors and 6 fine artists from Slovenian, Czech and Polish circle and their activities are indicated in the selected examples of guest exhibitions in Zagreb, Vienna and Prague.

56 Female Croatian artists who exhibited their works at the exhibitions organised by the Society of Croatian Artists, that is the Croatian Art Association, were more present than female artists who were affiliated to the Polish Art Association Szutka or the Manes. Jelka Stuppi Leopoldina Auer-Schmidt, Zora Preradović, Slava Raškaj, Anka Löwenthal Maroičić and Nasta Rojc had regular appearances on the exhibitions in Zagreb and abroad. To learn more about education of Croatian female artists and exhibitions of their works during the late 19th and the early 20th century see: Ljiljana Kolešnik, "(Ne) moguća priča. Utjecaj münchenske Akademije na žensku umjetnosti ranog modernizma," in Akademija likovnih umjetnosti u Münchenu i hrvatsko slikarstvo, eds. Irena Kraševac, Petar Prelog and Ljiljana Kolešnik (Zagreb: Institute of Art History, 2008), 88-107; Darija Alujević, "Beč kao mjesto formiranja umjetnica hrvatske moderne i njihov udio u likovnom životu Zagreba," in Izazov moderne: Zagreb - Beč oko 1900 (exhibition catalogue) eds. Irena Kraševac and Petra Vugrinec (Zagreb: Klovićevi Dvori Galery, 2017), 125-174; Darija Alujević, "Women Artists of Croatian Modernism," in The Challenge of Modernism: Vienna and Zagreb around 1900 (exhibition catalogue), eds. Stella Rollig, Irena Kraševac and Petra Vugrinec (Vienna: Belvedere, 2017), 130-138. s that Czech and Polish artists made better use of their position in Vienna as a result of conditions provided to them by their art associations while Croatian and Slovenian artists had to organise themselves because their national associations did not have continuous or persistent activities. ${ }^{57}$ Bringing the Slovenian Art Association, the Mánes Association of Fine Artists and the Association of Polish Artists Sztuka to Zagreb open doors o a better critical angle for Croatian artists (artists from Zagreb), audience and critique and strengthened the domestic position of artists facing turbulent phases in the beginning of the 20th century due to their inner disputes. By switching their membership from one art association to another, their international position was weakened by the end of the 19th century after their appearance on the Millennial Exhibition in Budapest and guest exhibitions in Copenhagen, St. Petersburg and Paris after that.

57 Žerovc, Slovenski impresionisti, 75. The author explains that the Slovenian Art Association organised activities for only a brief period of time because of reasons related to its members' reluctance and various political plots. Another association named "Sava" was more successful and managed to organise a group exhibition at the u Miethke Gallery in 1904. http:// digitale-bibliothek.belvedere.at/viewer/ image/1433925050448/1/LOG_0000/ 
grebu 1911. od 1. svibnja do 1. lipnja. (Exhibition cat-

Kraševac, Irena. Ivan Meštrović i secesija. Beč München - Prag: 1900.-1910. Zagreb: Institut za povijest umjetnosti, and Fundacija Ivana Meštrovića, 2002.

Kraševac, Irena, and Željka Tonković. "Umjetničko umrežavanje putem izložaba u razdoblju rane moderne - sudjelovanje hrvatskih umjetnika na međunarodnim izložbama od 1891. do 1900. godine". Radovi Instituta za povijest umjetnosti, no. 40 (2016): 203-17.

Kraševac, Irena, and Petra Vugrinec, eds. Izazov moderne: Zagreb - Beč oko 1900, exhibition catalogue. Zagreb: Galerija Klovićevi dvori, 2017.

Kraševac, Irena, ed., 150 godina Hrvatskog društva likovnih umjetnika. Umjetnost $\mathrm{i}$ institucija. Zagreb: $\mathrm{Hr}-$ vatsko društvo likovnih umjetnika, Institut za povijest umjetnosti, 2018.

Kršnjavi, Izidor. "Druga izložba Društva hrvatskih umjetnika, I. Slovenski slikari," Narodne novine, December 31, 1900.

Krzysztofowicz-Kozakowska, Stefania, and Piotr Mizia. "Sztuka-Wiener Secession-Mánes. The central European Art Triangle," Artibus et Historiae, vol. 27, no. 53 (2006): 217-259.

Maruševski, Olga. Društvo umjetnosti 1868.-1879.-1941. Zagreb: Društvo povjesničara umjetnosti Hrvatske, 2004.

Milčinović, Andrija. “Umjetnička izložba," Savremenik, no. 8 (1911): 526-529.

Rollig, Stella, Irena Kraševac, and Petra Vugrinec, eds. The Challenge of Modernism: Vienna and Zagreb eds. The Challenge of Modernism: Vienna and Zagreb
around 1900, exhibition catalogue. Vienna: Belvedere,

Secessioni Europee. Monaco, Vienna, Praga, Roma, Palazzo Roverella, exhibition catalogue. Rovigo: Silvana Editoriale, 2017.

Wilhelmi, Christoph. Künstlergruppen in Deutschland, Österreich und der Schweiz seit 1900. Ein Handbuch, Stuttgart: Dr. Ernst Hauswedell \& Co., 1996.

Žerovc, Beti. Slovenski impresionisti. Ljubljana: Mladinska knjiga, 2013.

\section{ONLINE SOURCES}

Belvedere. "HAGENBUND. Ein europäisches Netzwerk der Moderne (1900 bis 1938)". Accessed January 5, 2019. http://tools.fas.at/hagenbund/exhibition.html
ArtHist Austria. "Exhibitions of Modern European Paintarthist.at/projektdetail/exhibitions-of-modern-eur pean-painting-1905-15.html

DALIBOR PRANČEVIĆ

Between Art Nouveau and the Avant-Garde: The Personal (Ego) Network of Ivan Meštrović and the Map of Critical Reception of His Work during the 1910s pp. 38-62

"Rus o Meštroviću". Srbobran April 4, 1911.

"Ruski glas o Meštroviću". Narodni list September 9, 1911.

"Ruski sud o Meštroviću". Brankovo kolo October 13, 1911.

Bulimbašić, Sandi. Društvo hrvatskih umjetnika "Medulić (1908.-1919.). Zagreb: Društvo povjesničara umjetnosti Hrvatske, 2016.

Clegg, Elizabeth. "Meštrović, England and the Great War." The Burlington Magazine, no. 144, (December 2002) 740-751.

Ivančić, Jasna, and Sanja Kreković-Štefanović, eds. Građa za bibliografiju Ivana Meštrovića od 1899. do 1993. Zagreb: Fundacija Ivana Meštrovića, Nacionalna i sveučilišna biblioteka, 1993.

Kečkemet, Duško. Život Ivana Meštrovića (1883.-1962. 2002.), Vol. I and Vol. II. Zagreb: Školska knjiga, 2009.

Kečkemet, Duško. Ivan Meštrović: Bibliografija 1899-2002. Split: Filozofski fakultet u Splitu, Duško Kečkemet, 2017. knjiga je u tisku.

Kraševac, Irena. Ivan Meštrović i secesija. Beč - München - Prag: 1900.-1910. Zagreb: Institut za povijest umjetnosti, and Fundacija Ivana Meštrovića, 2002.

Machiedo Mladinić, Norka. "Prilog proučavanju djelovanja Ivana Meštrovića u Jugoslavenskom odboru." Časopis za suvremenu povijest, vol. 39, no. 1 (June 2007): 133-156.

Meštrović, Ivan. Uspomene na političke ljude i događaje. Zagreb: Matica hrvatska, 1969.

Milačić, Karmen. Talijanska pisma Ivanu Meštroviću 1911 1921. Zagreb: Globus, 1987.

Prančević, Dalibor. "Odjek Ivana Meštrovića u Velikoj Britaniji nakon izložbe u Victoria \& Albert Museumu". In Zbornik II. kongresa hrvatskih povjesničara umjetnosti, Z5 403 . Zagreb: Institut za povjest umjenc
Prančević, Dalibor. "Sculpture by Ivan Meštrović at the Grafton Galleries in 1917: critical and social contexts." Sculpture Journal, vol. 25, no. 2 (2016): 177-192.

Prančević, Dalibor. Ivan Meštrović i kultura modernizma: ekspresionizam i Art déco. Split: Filozofski fakultet u Splitu, Muzeji Ivana Meštrovića, 2017.

Scott, John. Social Network Analysis: A Handbook. London: Sage Publications, 2000.

Vujanović, Barbara. "Doticaji umjetnika: Auguste Rodin i Ivan Meštrović". In Rodin u Meštrovićevu Zagrebu, edited by Jasminka Poklečki Stošić and Barbara Vujanović, 60-84. Zagreb: Umjetnički paviljon, Muzeji Ivana Meštrovića, 2015

\section{ARCHIVAL SOURCES}

Atelier Meštrović Archives, Letters collection, Zagreb.

University of Notre Dame Archives, Notre Dame, Indian 46556, Ivan Meštrović Papers, 1924- 1962.

\section{ONLINE SOURCES}

Bentkowska-Kafel, Ana. "Debating Digital Art History. International Journal for Digital Art History, no. 1 (2015) 50-64. https://doi.org/10.11588/dah.2015.1.21634b

TAMARA BJAŽIĆ KLARIN, NIKOLA BOJIĆ

CIAM Network Visualisation - Detecting Ideological Ruptures in the CIAM Discourse pp. 64-82

Anon., "Architecture et urbanisme en U.R.S.S." L'Architecture d'Aujourd'hui, no. 8 (1932): 49-96.

Bjažić Klarin, Tamara. Ernest Weissmann: društveno angažirana arhitektura, 1926 - 1939/Ernest Weissman Socially Engaged Architecture, 1926-1939. Zagreb: Hrvatska akademija znanosti i umjetnosti, Hrvatski muze arhitekture, 2015.

Bjažić Klarin, Tamara. "CIAM Networking - Internationa Congress of Modern Architecture and Croatian arch tects in the 1950s." Život umjetnosti, no. १९ (2016), 40-57. tectsin the 1950." Zivot umje science?" Papers of the Regional Science Association science?" Papers
no. 1 (1970): 6-21.

Huber, Benedikt. Die Stadt des Neuen Bauens. Projekte und Theorien von Hans Schmidt. Zürich: gta ETH, 1993.

Mumford, Eric. The CIAM discourse on urbanism, 1928 1960. Cambridge, Mass.: MIT Press, 2000.

Risselada, Max, and Dirk van den Heuvel, eds. Team 